\title{
Commentationis dispositio.
}

1) Quae sint rerum causae ab Aristotele constitutae (p. 1).

2) Unde illas petierit (p. 2-3).

3) Proferuntur et examinantur argumenta quibus ut causam finalem in rerum natura agnoscendam esse demonstraret usus est (p. 3-8).

4) Rei finem contineri opere exsequendo (p. 8-9).

5) Opus exsequendum constituere rei naturam, ita ut causa formalis e causa finali pendeat (p. 9-12).

6) Cogitationis primum esse ultimum ortus (p. 12-14).

7) Causam finalem esse principium motionis (p. 15-16).

8) Quattuor causarum inter se necessitudo consideratur ratione habita Met. Z, 7 (p. 16-18).

9) De materiae apud Aristotelem natura (p. 18-20).

10) Confertur ei materia doctrinae Platonicae (p. 20-21).

11) Formam immotam movere materiam (p. 2l-22).

12) Causam materialem Aristotelem e causa finali ducere non potuisse (p. 23-24).

13) Neque magis Platonem voluisse materiam originem habere a deo (p. 24).

14) Causam finalem efficere rei unitatem (p. 25-26).

15) Corporis partes singulas singularum et omnes omnium ratione habita procreari (p. 27).

16) Totum partibus esse prius (p. 28).

17) Partes inferioris gradus servire praestantioribus potioribusque (p. 28-30).

18) Idem cerni in rerum naturalium ordinibus et in vita hominum (p. 30).

19) Hominibus ineundas esse societates (p. 30-34).

20) Finem bonum aliquod esse (p. 34-36).

21) Naturas omnes appetere actum vitam acternitatem (p. 36-37).

22) Fines hominum esse multos ideoque etiam bona multa (p. 38).

23) Qui finis et quod bonum hominis proprium sit (p. 38-39).

24) Societates quae sint secundum naturam in bonorum numero esse habendas (p. 40). 
25) Summum bonum immanens esse mundi ordinem (p. 40-44).

26) De necessitate hypothetica (p. 44-52).

27) Quem locum Plato materiae eiusque viribus tribuerit (p. 52-53).

28) De casu et forte (p. 54-56).

29) De privatione (p. 56-65).

30) Statuendum esse motorem primum (p. 65).

31) Eundem esse immotum, aeternum, substantiam, actum, summum finem $(65-67)$.

32) Eundem esse intellectum atque vita uti beatissima (p. 67-71).

33) Quid sibi velit dictum illud: cogitationem esse cogitationis cogitationem sive intellectum cogitare semet ipsum (p. 71-78).

34) Quid cogitet deus (p. 78-83).

35) Quo deus cogitationes adducat ad effectum (p. 83-85).

36) Quae ratio inter deum et materian oit, ab Aristotele expositum hon esse (p. 85-86).

37) Deo neque quidquam esse praeteritum neque futurum, sed praesentia omnia (p. 86).

38) Deum esse causam essendi et cognoscendi (p. 87-88).

39) Proferuntur aliorum de dei apud Aristotelem natura sententiae (p. 89-98).

40) Occurritur argumento quod aliquis contra nostram de deo Aristoteleo existimationem repetere possit ex idearum doctrina ab Aristotele improbata (p. 98-102).

41) Excursus (p. 103-119).

42) Index locorum ubi codicum verba mutavimus (p. 120). 